\title{
Comparative evaluation between atmospheric and sub-baric processing of Gulabjamun
}

\author{
Sharanabasava, Menon Rekha R, Praveen Kumar Y S, M Manjunatha, G Mahesh Kumar and BS Nath
}

Received: 15 January 2019 / Accepted: 29 March 2019 / Published online: 22 June 2019

(C) Indian Dairy Association (India) 2019

\begin{abstract}
Gulabjamun, a popular Indian dairy sweet, is characterised with a brown crust and a soft, slightly spongy core with a uniform granular texture and a pleasant cooked flavour. Sub-baric processing is a novel technology which uses low temperature, low pressure and minimal exposure to oxygen which ultimately improves the quality parameters of fried foods. An attempt was made to compare conventional and sub-baric processed Gulabjamun in terms of its sensory, physical, chemical and microbial attributes. The processing conditions for frying were $118^{\circ} \mathrm{C} / 5 \mathrm{~min} / 80 \mathrm{kPa}$ vacuum and $140^{\circ} \mathrm{C} / 8 \mathrm{~min}$ (under atmospheric pressure) for sub-baric frying and conventional frying, respectively. The soaking conditions were $60^{\circ} \mathrm{Brix}$ at $30^{\circ} \mathrm{C}$ for $5 \mathrm{~min}$ for sub-baric soaking and $63^{\circ} \mathrm{Brix} / 60^{\circ} \mathrm{C} / 4 \mathrm{~h}$ for conventional soaking. The sub-baric frying of Gulabjamun resulted in reduced oil and moisture content in the final product. Microbial enumeration also indicated a lower count in sub-baric fried product when compared to conventionally fried Gulabjamun. The colour of both samples was comparable while the textural properties were found to be better for sub-baric processed product. Sensory score for overall acceptability based on 9 point hedonic scale were 8.2 and 7.14 for sub-baric processed and conventional product, respectively. Apart from these advantages, sub-baric processing recorded significantly less processing time than the conventional method.
\end{abstract}

Sharanabasava ( $₫)$, Menon Rekha R, Praveen Kumar YS, M

Manjunatha

Department of Dairy Engineering,

SRS of ICAR-NDRI, ,Adugodi, Bengaluru 560030, India

Email: sharankumbar111@gmail.com; Phone : +91-8867422464

G Mahesh Kumar

Dairy Science College, Hebbal, Bengaluru 560 024, India

BS Nath

Department of Dairy Chemistry,

SRS of ICAR- NDRI, Adugodi, Bengaluru 560 030, India
Keywords: Frying, Gulabjamun, Quality, Soaking, Sub-baric

\section{Introduction}

Gulabjamun is prepared from dough kneaded by blending standardised proportions of heat desiccated milk (khoa) and refined wheat flour (maida), sometimes with a suitable leavening agent such as baking powder and required quantity of water. The portioned dough is rolled in to smooth balls and deep fried in oil or ghee till a brown crust is achieved followed by soaking in sugar syrup to infuse the desired juiciness and sweetness in the product. Thus, deep fat frying (DFF) and soaking form two important unit operations in the preparation of this product.

DFF is one of the oldest and most popular cooking methods in existence (Varela, 1988), which involves cooking by immersing a food product in edible fat or oil at a temperature above the boiling point of water, usually $150-200^{\circ} \mathrm{C}$ (Farkas et al. 1996). During frying, the quality attributes such as physico-chemical, textural, optical, thermal and dimensional properties of food gets transformed as a consequence of frying-induced thermal reactions such as gelatinization of starch, denaturation of proteins, hydrolysis, development of flavours, Maillard browning, caramelization and inactivation of enzymes (Sahin and Sumnu 2009). The process leads to a simultaneous dehydration or moisture loss from the food along with fat uptake (Haak et al. 2007).

Soaking is a unit operation in food processing where the product is immersed in a bath of solute(s), often at elevated temperatures for a specified duration, so that the solute/ solution (often sugar or salt) diffuses in to the core of the food product, imparting flavour in the product and also enhancing its shelf life. Soaking is also influenced by process conditions such as syrup concentration temperature and time and the absorption of soaking syrup and moisture into the product affects the body and texture of the product, primarily the expansion and juiciness of the product. (Barat et al. 2002)

In recent times, there has been an interest in vacuum or sub-baric processing, wherein the basic unit operations in food processing are carried out at pressures below atmospheric pressure. Sub- 
baric frying, like conventional frying, has been found to result in change in colour and appearance, body and texture and product composition, rendering the fried product palatable to the consumer. At the same time, several inherent benefits in terms of product quality have been reported for sub-baric frying over conventional process attributed to the low temperatures used and the minimal exposure to oxygen, which reduces the adverse effects on the oil quality, preserves the natural colour and flavour and nutritional value of the fried product (Yamsaengsung et al. 2011). The process has been applied to a wide variety of food products including snacks and sweets and large application of this technology is reported for fruits and vegetables fried chips, such as, apple, apricot, banana, jackfruit, green and gold kiwifruits, carrot, mushroom, potato, shallot, sweet potato and purple yam.(Diamante et al. 2015 ).

Sub-baric soaking is described as a non-destructive method where a solution is introduced with a specific composition to the porous matrices of product; the mass transfer takes place as a result of induced differences in pressure. This makes it possible to fill large volumes of intercellular spaces in tissues of fruit and vegetables, thus altering physico-chemical properties and sensory attributes of the soaked products. Several reports have cited the advantages of this process over conventional soaking in candying operations and rehydration of dried fruits and vegetables; including, savings in processing time, improved absorption capacity of the product and energy savings due to processing at ambient temperature. (Luciana et al. 2005, Fito et al. 1996, Barat et al. 2002).

Kumar and Ravindra (2016) reported on the development of a sub-baric thermal processor (SBTP) for the preparation of fried and soaked dairy products. The standardization of the process protocol for vacuum impregnation of sugar syrup into fried Gulabjamun balls has been highlighted in Sharanabasava et al. (2018, 2019). A comparative evaluation of the quality and acceptability of Gulabjamun prepared using sub-baric frying and soaking process against the product prepared using conventional processing protocols is presented in this study.

\section{Materials and methods}

\section{Preparation of Gulabjamun balls}

Cow milk was collected from the Experimental Dairy of ICARNational Dairy Research Institute, Bengaluru, India. The milk was standardized to $4.0 \%$ fat and $8.5 \%$ solids-not-fat (SNF). Khoa was obtained by evaporating the standardized milk in an open steam-jacketed kettle (steam pressure: $196.13 \mathrm{kPa}$ ) with continuous stirring and scraping until a semisolid dough (35\% TS) was obtained. Maida and refined sunflower oil (brand: Fortune, Adani Wilmar Limited, Ahmedabad, India) were procured from the local market. Khoa was then blended with 30\% Maida and the ingredients were kneaded in a planetary mixer to obtain smooth dough (De, 2003).

\section{Frying of Gulabjamun}

The process flow chart for the frying and soaking of Gulabjamun by both the sub-baric and conventional process is depicted in Fig. 1. In the conventional process, the prepared dough (along with baking powder $0.6 \%$ on khoa basis) was portioned into units of $10 \mathrm{~g}$ each and then manually rolled to smooth spherical balls. These balls were fried by immersing in a hot oil bath carefully monitored at $140^{\circ} \mathrm{C}$ for 8 min until golden brown colour for the crust was obtained (Devaraja, 2005). In the sub-baric process, the portioned Gulabjamun balls (rolled manually) from the kneaded dough (without the baking powder) were processed in a sub-baric thermal processor (SBTP) that was designed and fabricated in-house (Kumar and Ravindra, 2016). The SBTP consists of a parallel vacuum frying chamber and a vacuum soaking chamber. The Gulabjamun balls were loaded into the trays of the unit and loading basket was lowered in to the heated oil bath by running the automated hoist system of the unit.

Vacuum pressure is known to have a significant effect on the oil absorption and moisture loss during frying (Garayo and Moreira, 2002). Hence, it was attempted to create maximum possible vacuum $(90.74 \mathrm{kPa}$, corresponding to the atmospheric pressure at Bengaluru) during the frying of the product. However, it was observed that the Gulabjamun balls lost its shape and integrity under the severe vacuum pressure. Trials were conducted for upward correction of the vacuum pressure during the frying and a vacuum of $80 \mathrm{kPa}(400 \mathrm{mmHg})$ was deemed satisfactory for frying of this product. Further, this was in agreement with Kumar (2016) who suggested a combination of $118^{\circ} \mathrm{C}$ for $5 \mathrm{~min}$ at $400 \mathrm{~mm}$ $\mathrm{Hg}$ for sub-baric frying of Gulabjamun.

\section{Soaking of Gulabjamun}

The methodology recommended by Devaraja (2005) for conventional soaking of the fried Gulabjamun was followed for this study (Fig. 1). The fried balls were soaked in sugar syrup of concentration $63^{\circ} \mathrm{Brix}$ at $60^{\circ} \mathrm{C}$ for $4 \mathrm{~h}$. The balls were held immersed in the sugar syrup by inserting a perforated basket into the sugar syrup bath. After the elapse of the soaking time, the soaked product was withdrawn from the syrup and used for analysis. For sub-baric soaking of the fried Gulabjamun balls, the following standardised process was followed (Sharanabasava et al. 2019). The balls were loaded in perforated trays and the tray was introduced in the soaking unit of the SBTP with a bath of sugar syrup $\left(60^{\circ}\right.$ Brix $)$ in the tank section at the bottom of the unit. The tray was held suspended in the headspace of the unit and a vacuum of $90.74 \mathrm{kPa}(680 \mathrm{mmHg})$ was created by running the vacuum pump. After a lapse of $5 \mathrm{~min}$, the tray was lowered into the syrup bath by activating the automatic hoist system. Once the tray was immersed in the bath, the vacuum was immediately 
released and the balls were held immersed in the bath at $30^{\circ} \mathrm{C}$ for a period of $5 \mathrm{~min}$. The tray was then lifted above the syrup bath using the automatic hoist and removed from the SBTP to withdraw the soaked product for further analysis. For comparison of quality attributes of conventionally prepared product with the Gulabjamun prepared using the sub-baric process, the sugar syrup of was used in the soaking experiments

\section{Determination of oil content}

About $1 \mathrm{~g}$ of the representative ground sample was taken in 100 $\mathrm{mL}$ beaker. The fat content was determined using the Mojonnier fat extraction apparatus explained in BIS (1981). The samples were digested using $10 \mathrm{~mL}$ of concentrated hydrochloric acid and were then added with $10 \mathrm{~mL}$ of ethyl alcohol. Fat was extracted with $25 \mathrm{~mL}$ each of diethyl ether and petroleum ether. The extraction was repeated 3 times and the superficial layer was decanted to a beaker of predetermined weight. The solvents were evaporated completely in a water bath. The residue obtained was dried in hot air oven at $100 \pm 2^{\circ} \mathrm{C}$ for $1 \mathrm{~h}$.

\section{Determination of Moisture content}

The whole Gulabjamun was ground using pestle and mortar. From the ground mass, about $5 \mathrm{~g}$ of the sample was taken and weighed accurately. The moisture content of the Gulabjamun was determined using oven drying method prescribed for hard cheese with slight modification (AOAC, 2005)

\section{Measurement of crust colour}

The crust colour of Gulabjamun at optimised stages of frying was measured using a computer based image analysis technique. The samples were placed on a flatbed scanner (Canon scanner mark 2000) and scanned at $1280 \times 720$ dpi resolution. The images were then imported into Adobe Photoshop 7.0 software and the ' $L$ ', ' $a$ ' and ' $b$ ' values were obtained from the histogram window. According to International Commission of Illumination (CIE, 1986), a colour can be defined by three parameters namely lightness $\left(\mathrm{L}^{*}\right)$ and the two chromatic components $\left(\mathrm{a}^{*}\right.$ and $\left.\mathrm{b}^{*}\right)$. These values were converted into CIELAB L*, $a^{*}$ and $b^{*}$ values and the Browning index was derived using the following formulae (Yam and Papadakis, 2004)

$$
\begin{aligned}
& L^{*}=\left[\frac{L}{255}\right] \times 100 \\
& a^{*}=\left[\frac{240 a}{255}\right]-120
\end{aligned}
$$

$$
\begin{aligned}
& b^{*}=\left[\frac{240 b}{255}\right]-120 \\
& B I=\left[\frac{100(Z-0.31)}{0.17}\right] \\
& Z=\frac{\left(a^{*}+1.75 L^{*}\right)}{\left(5.645 L^{*}+a^{*}-3.012 b^{*}\right)}
\end{aligned}
$$

\section{Determination of textural properties}

Textural profile analysis (TPA) was performed using TA.XT Plus Texture Analyzer (Stable Micro Systems, Texture Technologies Corp., Goldaming, UK) equipped with $50 \mathrm{~kg}$ load cell TPA was done to characterize the hardness, springiness, cohesiveness, chewiness and gumminess.

\section{Determination of porosity}

The porosity of the fried Gulabjamun balls (by conventional and sub-baric method) were estimated using a protocol based on an image texture processing technique reported by Wasnik et al. (2017). The method involved the scanning of a cut away section of the fried product and importing the image to ImageJ $1.34 \mathrm{~s}$ software (National Institutes of Health, Bethesda, MD, USA). The images were cropped and converted to grey scale (8 Bit). The brightness and contrast of the image was corrected using the auto - adjusted option of the software and the image threshold value was adjusted using Otsu thresholding, which is a global thresholding selection method based on spatial clustering and widely applied in image processing applications. The thresholding operation resulted in binary images with maximised separation of the air vacuoles or pores. The "Analyse Particle" menu of the software was then employed to compute the area fraction of the pores to derive the porosity of the sample in $\%$ area of the product.

\section{Measurement of juiciness}

The method proposed by Jauregui et al. (1981) with slight modifications was employed to estimate this parameter. One whole Gulabjamun ball after soaking was placed in a graduated centrifuging tube $(50 \mathrm{ml})$ and centrifuged at $5000 \mathrm{rpm}$ for $5 \mathrm{~min}$. The volume of supernatant sugar syrup that was expelled from the product was then measured by reading the graduations on the centrifuging tube and recorded as juiciness of the product.

\section{Microbial analysis}


Microbial quality of the fried Gulabjamun balls was enumerated in terms of the total bacterial counts of the samples using standard plating methods in milk. Agar plates incubated at $37^{\circ} \mathrm{C}$ for $48 \mathrm{~h}$. The product fried using the conventional process and using sub-baric frying was analysed for its microbial counts.

\section{Sensory evaluation of the product}

The organoleptic quality of the Gulabjamun was evaluated by a panel of 8 judges on a 9-point hedonic scale. The sample of Gulabjamun was analyzed for sensory parameters like, colour and appearance, flavour, body and texture and overall acceptability. Wherein a score of 1 represented 'dislike extremely' and score of 9 represented 'like extremely', the samples for evaluation were served to the judges for sensory evaluation.

\section{Statistical analysis}

All experiments were carried out in triplicate (Table 1) and the experimental data was subjected to statistical analyses using Microsoft Excel 2010 and SPSS (v. 15. 0). The effect of sub-baric and conventional frying and soaking on quality parameters of Gulabjamun were analyzed in terms of its ANOVA ( $\mathrm{p}$ value of 0.05 was used as the cut-off for significance).

\section{Results and discussion}

\section{Oil uptake}

The fat content of Gulabjamun fried by the conventional and sub-baric process obtained during this study is presented in Table 2. It has been widely reported in literature that vacuum frying resulted in significantly lower oil content in comparison to atmospheric fried food products (Dueik and Bouchon, 2011). This has been attributed to the low pressure during frying that results in faster diffusion of air into the porous structure developed in the product during frying, blocking passage of oil into the product leading to lower absorption of oil. In the sub-baric process, post - frying, the basket with the fried Gulabjamun balls were lifted and held in the headspace of the unit for 5 min under a vacuum at $90.74 \mathrm{kPa}$ to drain out most of the oil; this critical step in the subbaric frying processing helped reduce the oil content of the product significantly. The fat values for the fried Gulabjamun increased from initial values of $14.5 \%$ to $31.05 \pm 1.90 \%$ for the conventional fried product and $19.78 \pm 1.43 \%$ for the sub-baric fried product.

Gamble et al. (1987) reported that when the product is fried, the inner moisture was converted to steam, which created a pressure gradient as the surface dried out, causing the oil to adhere to the product's surface and enter inside. The authors also stated that the fat content was not directly related to frying temperature itself, but was rather closely associated with the final moisture content, which was, in turn, affected by temperature. The fat content of Gulabjamun obtained for both the frying processes inversely related to its moisture content which was in agreement to the trend reported by Franklin et al. (2013).

\section{Moisture content}

Gulabjamun undergoes simultaneous heat and mass transfer during deep fat frying resulting in mass transfer due to simultaneous moisture evaporation from the product and oil absorption in to the product. The moisture content of Gulabjamun fried by the conventional and sub-baric process is presented in Table 2. The moisture content in sub-baric fried Gulabjamun decreased from an initial value of $61.91 \pm 2.13 \%$ (for the prepared dough ball) to $8.87 \pm 2.13 \%$ in the final product (Table 2 ). Similarly, in the case of the conventionally fried product the moisture content decreased during frying, however, the final moisture content after 8 min of frying at $140^{\circ} \mathrm{C}$ was significantly higher than that of the sub-baric fried product at $20.91 \pm 1.20 \%$. These results are in accordance with the studies on comparison between atmospheric and vacuum frying of apple slices (Mariscal and Bouchon, 2008). The excess loss of moisture during subbaric frying has been attributed to the effect of low pressure in faster diffusion of the moisture from the product.

\section{Microbial quality}

Since the core temperature of the product during sub-baric frying was much lower due to the decrease in the boiling point of moisture under vacuum, concerns could be raised regarding the microbial quality of the product. Hence, microbial quality of the fried Gulabjamun balls was enumerated in terms of the total bacterial counts of the samples using standard plating methods. The product fried using the conventional process and using sub-baric frying was analyzed and the results are tabulated in Table 2. The TBC for the conventional fried Gulabjamun was found to be significantly higher $(1950 \pm 21.21 \mathrm{cfu} / \mathrm{g})$ than sub-baric fried product $(236 \pm 5.50 \mathrm{cfu} / \mathrm{g})$. This result was in contrary to the expectations of principles of thermal processing principles where a higher temperature during processing in expected to result in better microbial quality of the product. The obtained result is attributed to the fact that during the frying process and the later suspension of the sub-baric fried product in the equipment head space, the product is exposed to a vacuum of 80 and $90.74 \mathrm{kPa}$, respectively, for $5 \mathrm{~min}$ each (Fig. 1). This period resulted in exposure of the product to an atmosphere of reduced oxygen which would have adversely impacted the growth of microorganisms. A similar result of lower bacterial count was reported by Leisner et al. (1995) for their study on growth of selected lactic acid bacteria on storage life of beef stored under vacuum and in air.

\section{Crust colour}

The crust colour of the fried samples was measured in terms of $\mathrm{L}^{*}, \mathrm{a}^{*}, \mathrm{~b}^{*}$ and browning index (BI) values using image analysis. The $\mathrm{L}, \mathrm{a}, \mathrm{b}$ values obtained for the conventional product were 
$98.47 \pm 3.39,150.45 \pm 0.43$ and $165.79 \pm 2.12$, respectively and for sub-baric fried Gulabjamun were $109.31 \pm 6.55,146.84 \pm 0.54$

$$
\text { Gulabjamun balls (10 g) }
$$

Immersing in Oil bath $\left(140^{\circ} \mathrm{C}\right)$<smiles>CC1(C)CCCC1</smiles>

Frying with constant turning $(8 \mathrm{~min})$

$$
\checkmark
$$

Withdrawal of the fried balls

$$
\downarrow
$$

Fried Gulabjamun balls

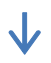

Immersion of fried balls into the syrup

$\left(63^{\circ} \mathrm{Brix}, 60^{\circ} \mathrm{C}\right)$

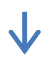

Soaking $(4 \mathrm{~h})$

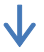

Soaked Gulabjamun balls

\section{$\underline{\text { A.Conventional method }}$}

and $170.49 \pm 1.69$, respectively. The $L^{*}, a^{*}$ and $b^{*}$ values were derived from this data using Eq. 1 to 3 and the BI for the samples

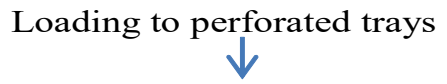

Transfer tray to sub-baric fryer<smiles>C[C@@H]1CC[C@@H]1C(C)(C)C</smiles>

Deep frying@

$118^{\circ} \mathrm{C}$ for 5 min@80kPa vacuum

Lifting of frying basket and suspend in head $\mathrm{s}$ ] for 5 min@90.74kPa vacuum

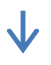

Breaking vacuum and taking out fried balls

Fried Gulabjamun balls

Loading of fried balls in tray of soaking unj

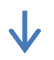

Suspension of tray containing balls in headsp of the unit (@vacuum of 90.74kPa/ 5min'

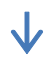

Lowering the tray into the syrup bath $\left(60^{\circ} \mathrm{Br}\right.$ $30^{\circ} \mathrm{C}$ ) and Instant release of vacuum

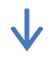

Holding of balls immersed in the syrup bat] (5min)

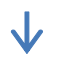

Lifting of tray

$\checkmark$

\section{Soaked Gulabjamun balls}

\section{B. Sub-baric method}

Fig.1 Method for preparation of fried Gulabjamun balls using (A) Conventional and (B) Sub-baric process 
Fig 2. Colour parameters of conventional and sub-baric fried Gulabjamun
Fig 3. Textural attributes for conventional and sub-baric fried and soaked Gulabjamun
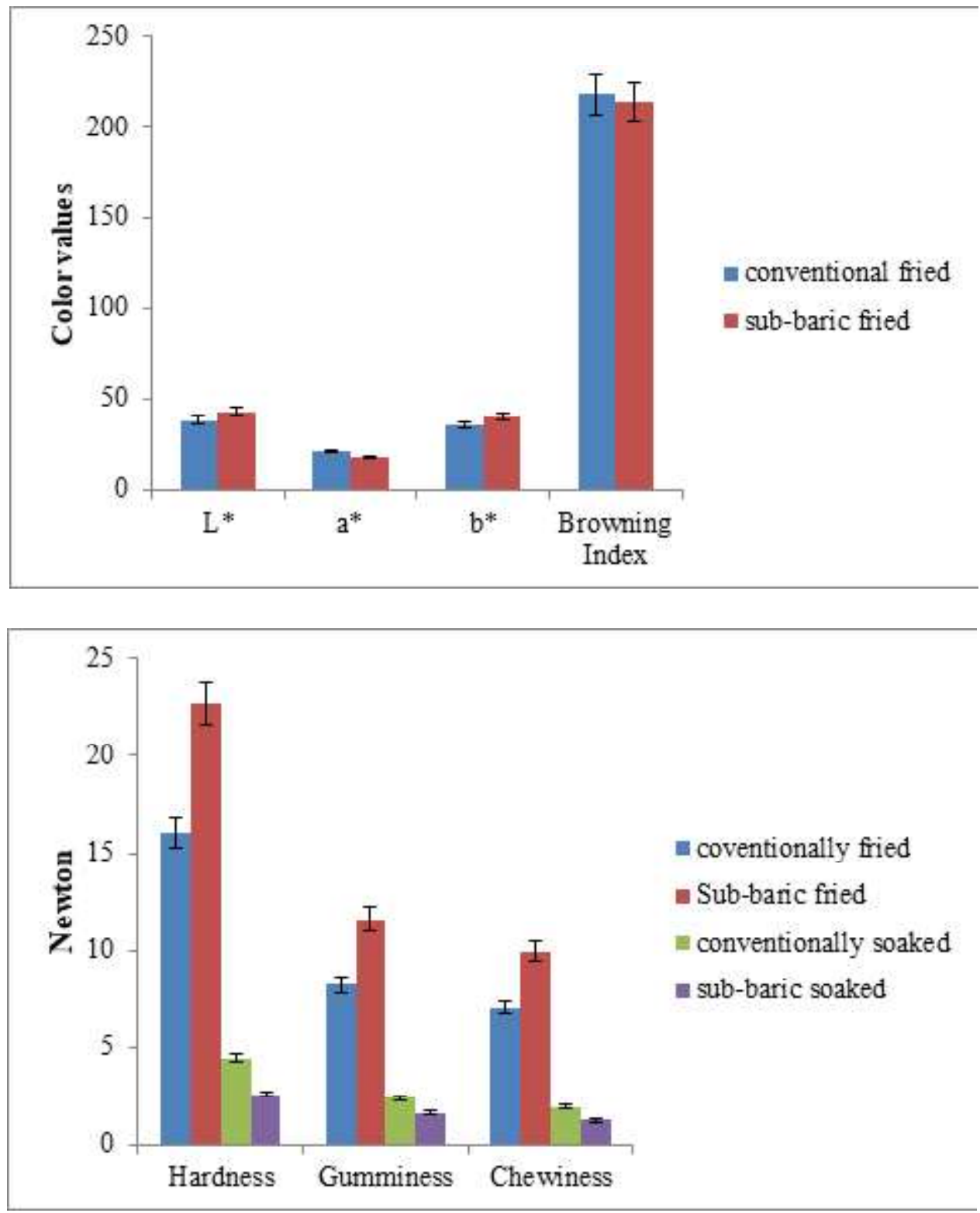

Table 1 Experimental design (full factorial) for the frying and soaking of Gulabjamun by conventional and sub-baric process

\begin{tabular}{lllll}
\hline Unit Operation & \multicolumn{2}{c}{ Process Parameters } & Replications \\
\hline & Temperature, ${ }^{\circ} \mathrm{C}$ & Time, min & Vacuum, $\mathrm{kPa}$ & 3 \\
Frying Conventional & 140 & 8 & - & 3 \\
Frying Sub-baric & 118 & 5 & 80 & \\
& Temperature, ${ }^{\circ} \mathrm{C}$ & Time, min & Vacuum, $\mathrm{kPa}$ & 3 \\
Soaking Conventional & 60 & 240 & - & 3 \\
Soaking Sub-baric & 30 & 5 & 90.74 & 3 \\
\hline
\end{tabular}

was computed using Eq 4 and the results are presented in Fig.2. It can be seen that the $\mathrm{L}^{*}, \mathrm{a}^{*}$ and $\mathrm{b}$ values obtained for the subbaric fried product were marginally varying from that recorded for conventional samples, while the BI values obtained for both samples were comparable (i.e. $218.02 \pm 1.60$ for conventionally fried product and $214.14 \pm 0.70$ for sub-baric fried Gulabjamun), indicating no appreciable difference in the crust colour of the samples fried using the two methods. The marginally higher BI 
Fig 4.Cohesiveness and Springiness for conventional and sub-baric fried and soaked Gulabjamun

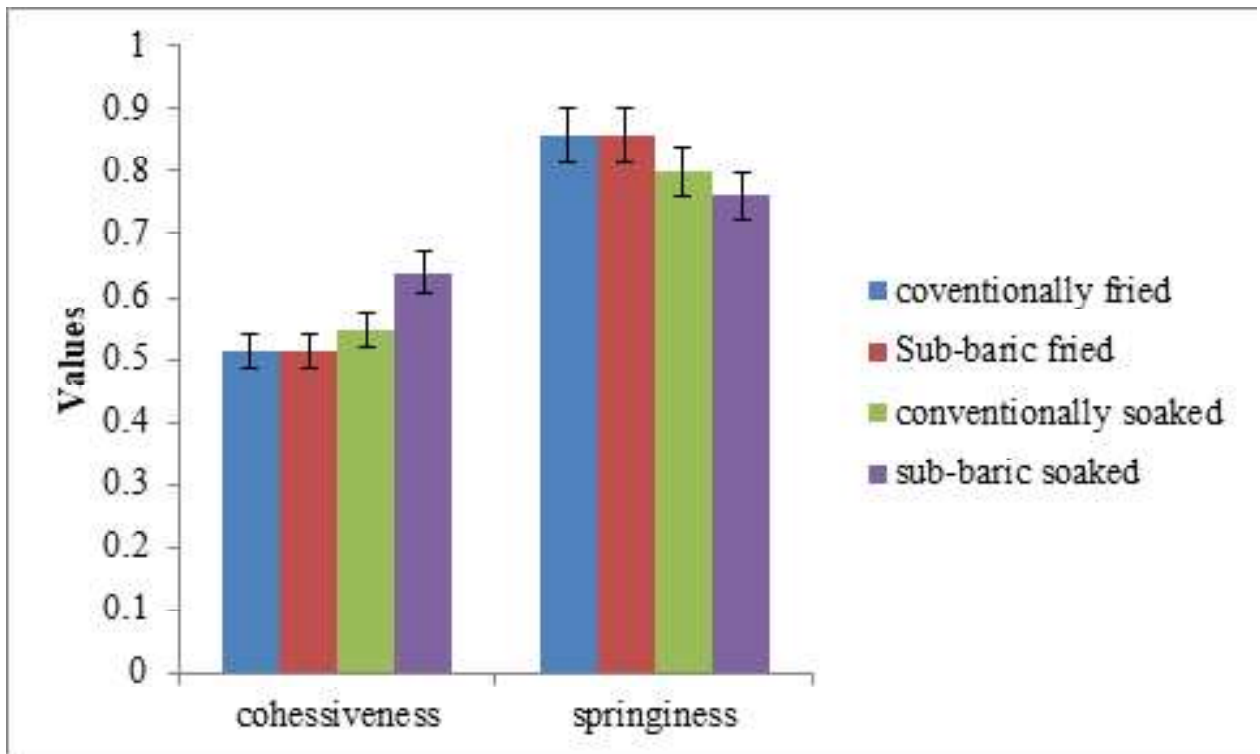

Table 2 Moisture content, Fat content and TPC of conventional and Sub-baric fried Gulabjamun

\begin{tabular}{llc}
\hline Parameters & Conventional 140p C/8 min & Sub-baric 118p C/5 min \\
\hline Moisture content(\% d.b) & $20.90 \pm 1.20^{\mathrm{a}}$ & $8.87 \pm 2.13^{\mathrm{b}}$ \\
Fat content (\%) & $31.05 \pm 1.90^{\mathrm{a}}$ & $19.78 \pm 1.43^{\mathrm{b}}$ \\
Total bacterial count (cfu/g) & $1950 \pm 21.21^{\mathrm{a}}$ & $236 \pm 5.50^{\mathrm{b}}$ \\
\hline
\end{tabular}

Means within a row which are not followed by a common superscript letter are significantly different $(P<0.05)$.

value for the conventionally fried product could be due to the higher frying temperature and time, resulting a slightly darker brown product; however, no significant effect of this was observed during the sensory evaluation of the product.

\section{Textural properties}

It can be observed from Fig. 3 that the properties like hardness, chewiness and gumminess were higher for sub-baric fried Gulabjamun than the conventional product; the hardness was significantly higher for the sub-baric product at $22.67 \mathrm{~N}$ when compared to $16.04 \mathrm{~N}$ obtained for the conventional product. This increased hardness of the sub-baric fried product also correlated with the reduced moisture content of the fried product. Similar results on products with higher hardness and crispiness using sub-baric frying for mango and potato have been reported by Da Silva and Moreira, (2008), who also attributed the observation to lower moisture content of the product. There was no significant difference between the cohesiveness and springiness values of fried Gulabjamun using both the processes indicating that the textural qualities of both products were comparable and soaked under both the methods.

The textural attributes of fried and soaked product (conventional and sub-baric) is presented in Fig. 3 and 4. Even though the subbaric fried product was harder than the conventionally fried samples, after soaking it was observed the product was softer (hardness $2.57 \mathrm{~N}$ ) than the conventional product (hardness
$4.42 \mathrm{~N})$. The reduced softness, gumminess, springiness and chewiness of the sub-baric product could be attributed to the enhanced absorption and retention of sugar syrup in to the product due to its higher porosity. The increased sugar syrup retention in sub-baric was also reflected in the higher juiciness obtained during its objective measurement. It can also be seen that the sub-baric soaked product had marginally higher cohesiveness (Fig. 4.), which is defined as the strength of the internal bonds making up the body of the product and is measured as the ability of the product to withstand a second deformation relative to its resistance under the first deformation (Anonymous, 2017).

\section{Porosity of the fried product}

Porosity is one of the important parameters of the fried product and was measured using the image processing technique. The porosity of the product was expressed in terms of $\%$ area of voidage in the cut section of the product and the pictorial transformation of the images of cut section of the fried product using conventional and sub-baric frying is presented in Fig. 5. The results indicated that porosity obtained for sub- baric fried sample was significantly higher at $45.28 \pm 2.89 \%$, while for the conventionally fired product the porosity obtained was $11.10 \pm 1.48 \%$. This result is significant on two accounts; (i) the dough for the sub-baric processed Gulabjamun was prepared without the addition of any leavening agents such baking powder, while baking powder@0.6\% (khoa basis) was added in the 
A

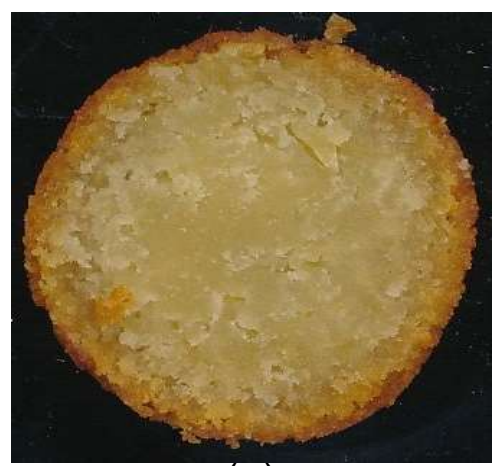

(a)

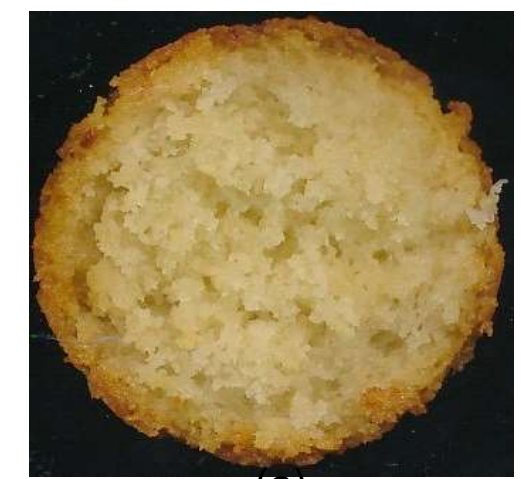

(a)

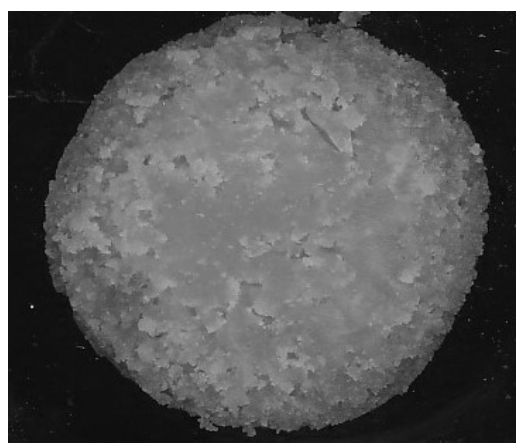

(b)

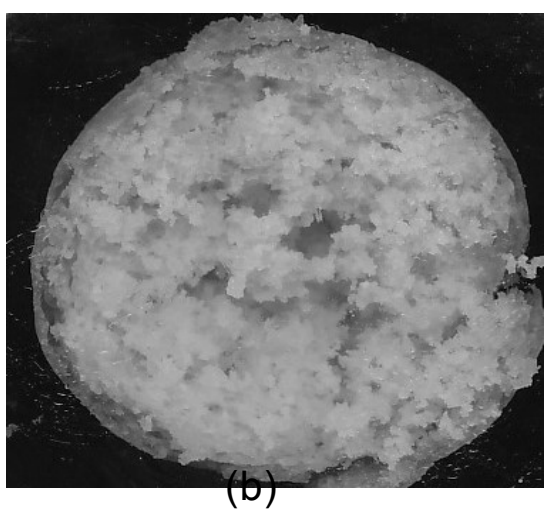

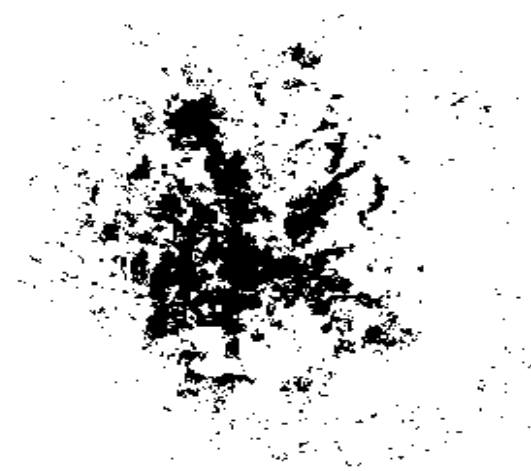

(c)

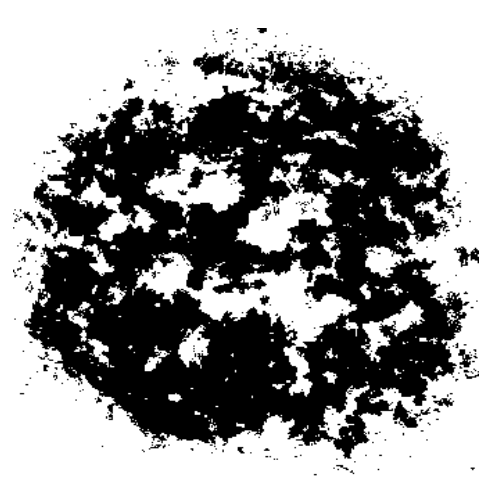

(c)

Fig 5. Porous structure of conventional (A) and sub-baric (B) fried Gulabjamun (a)Original image (b) Processed 8bit Image (c) Image after thresholding

Fig 6. Sensory score for sub-baric and conventional processed Gulabjamun

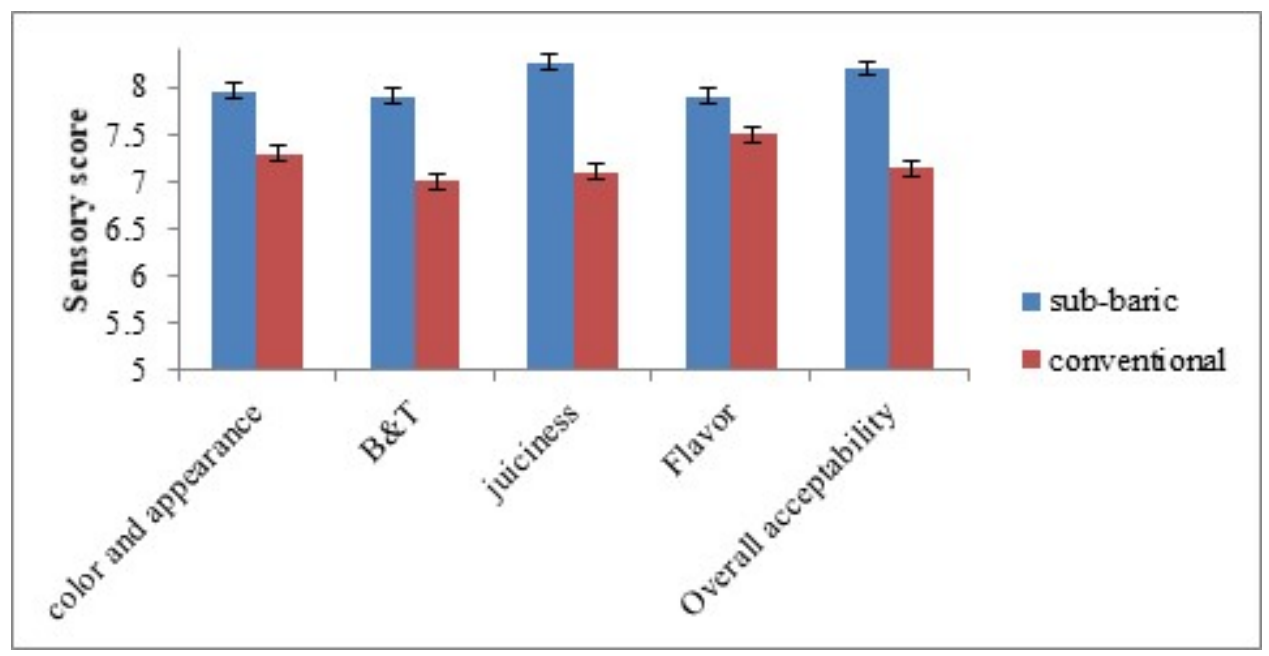

conventional product, in spite of this the porosity development in sub-baric product was superior to the conventional product (ii) porosity in products such as Gulabjamun has significant impact on the body and texture of the product as well as absorption of sugar syrup during soaking and resultant sweetness and juiciness (Kumar et al. 2006).

\section{Measurement of juiciness}

Juiciness is one of the important parameter influencing the acceptability of soaked Gulabjamun. The method proposed by Jauregui et al. (1981) with slight modifications was employed to estimate this parameter. It was observed that the sub-baric soaked product has significantly higher juiciness $(2.33 \pm 0.57 \mathrm{ml})$ in comparison to that of conventionally soaked product $(1.5 \pm 0.50$ $\mathrm{ml}$ ). The increased juiciness in the sub-baric soaked product could be attributed to the enhanced porosity of the fried product (Fito 
et al. 1996) and also the faster influx of the sugar syrup due to the hydrodynamic mechanism of vacuum impregnation discussed by Derossi et al. (2012). Similar increase in yield and enhanced influx of the solute during vacuum impregnation was reported for pineapple candy (Barat et al. 2002) and salted Minas cheese (Luciana et al. 2005)

\section{Sensory score}

The soaked product prepared by conventional and sub-baric process was subjected to sensory evaluation on a 9 - point hedonic scale and the average sensory scores obtained in terms of colour and appearance, flavour, body and texture, juiciness and overall acceptability are presented in Fig.6. The sensory scores obtained clearly indicated that the sub-baric processed Gulabjamun had superior scores for all the parameters evaluated, especially for the attributes of appearance, body and texture and juiciness. This may be due to the enhanced juiciness, sweetness and cohesiveness of the product.

\section{Conclusions}

The study compared the quality attributes of Gulabjamun prepared using conventional and sub-baric frying and soaking processes. It was observed that sub- baric frying resulted in balls with significantly lower oil content and superior microbial quality than the conventionally fried product. Further, the desired porosity was achieved without the addition of any leavening agent in its dough by the sub-baric process. Soaking time was significantly reduced from $4 \mathrm{~h}$ in conventional processing to about 10 min: initial depressurising ( $5 \mathrm{~min})$ and actual immersion $(5 \mathrm{~min})$ in sub-baric soaking. The juiciness of the sub-baric soaked Gulabjamun was significantly higher and sensory acceptance of the sub-baric processed Gulabjamun was greater than the conventionally processed product. The study established that sub-baric processing could be applied to similar fried and soaked dairy products to prepare products with enhanced quality attributes and acceptability.

\section{Acknowledgments}

The authors acknowledge fellowship and infrastructure received from ICAR-NDRI (SRS) to carry out the research work

\section{Reference}

Anonymous (2017) Overview of Texture profile analysis (TPA), www.texturetechnologies.com/texture-profile-analysis (Accessed 9th may 2017)

AOAC (2005) Official methods of analysis of AOAC international. Washington DC

Barat J M, Talens P, Barrera C, Chiralt A, Fito P (2002) Pineapple candying at mild temperature by applying vacuum impregnation. J Food Sci 67: 3046-3052
BIS (1981) ISI Handbook of Food Analysis. Part XI: Dairy Products (SP:18). Bureau of Indian Standards, New Delhi, India.

CIE (1986) Colorimetry. In: Technical report (15.2) Commission Internationale deL'Eclairage (CIE) Vienna, Austria

Da Silva P F, Moreira R G (2008) Vacuum frying of high-quality fruit and vegetable-based snacks. LWT-Food Sci Technol 41: 1758-1767

De, S (2003) Outlines of Dairy Technology. Oxford University Press New Delhi, India. (Appendix IV)

Derossi A, Pilli T D, Severini C (2012) The application of vacuum impregnation techniques in food industry. In: Scientific, health and social aspects of the food industry. Valdez B (Ed). IntechOpen Ltd, Croatia, pp 25-56

Devaraja, H C (2005) EnhaIntncement of shelf-life of enriched gulabjamoon by microwave processing. M. Sc. Thesis, KVAFSU, Bidar

Diamante L M, Shi S, Hellmann A, Busch J (2015) Vacuum frying foods: products, process and optimization. Intl Food Res J 22: 15-22

Dueik V, Bouchon P (2011) Development of healthy low-fat snacks: understanding the mechanisms of quality changes during atmospheric and vacuum frying. Food Rev Int 27: 408-432

Farkas B E, Singh R P, Rumsey T R (1996) Modeling heat and mass transfer in immersion frying I, model development. J Food Engg 29: 211-226

Fito P, Andres A, Chiralt A, Pardo P (1996) Coupling of hydrodynamic mechanism and deformation-relaxation phenomena during vacuum treatments in solid porous food-liquid systems. J Food Engg 27: 229-240

Franklin MEE, Pushpadass HA, Ravindra MR, Rao KJ, Nath BS (2013) Modeling the heat and mass transfer during frying of gulab jamun. $\mathrm{J}$ Food Proc Pres 38: 1939-1947

Gamble MH, Rice P, Selman JD (1987) Relationship between oil uptake and moisture loss during frying of potato slices from cv. Record UK tubers. Intl J Food Sci Technol 22: 233-241

Garayo J, Moreira R (2002) Vacuum frying of potato chips. J Food Engg 55: $181-191$

Haak L, Sioen I, Raes K, Camp JV, Smet SD (2007) Effect of pan-frying in different culinary fats on the fatty acid profile of pork. J Food Chem 102: 857-864

Jauregui CA, Regenstein J M, Baker RC (1981) A simple centrifugal method for measuring expressible moisture, a water binding property of muscle foods. J Food Sci 46: 1271-1271

Kumar AJ, Singh RRB, Patel AA, Patil GR (2006) Kinetics of colour and texture changes in Gulabjamun balls during deep-fat frying. LWTFood Sci Technol 39: 827-833

Kumar M G (2016) Design and development of microcontroller based subbaric thermal processor for manufacture of fried and soaked dairy products. Ph D Thesis ICAR- NDRI, Karnal

Kumar MG, Ravindra MR (2016) Optimization of shell thickness of subbaric fryer for manufacture of fried products using Finite Element Analysis. Invn J Res Technol Engg Manage 1: 6-15

Leisner JJ, Greer GG, Dilts BD, Stiles ME (1995) Effect of growth of selected lactic acid bacteria on storage life of beef stored under vacuum and in air. Intl J Food Microbiol 26: 231-243

Luciana HC, Souza JAR, Laurindo JB (2005) Use of dyed solutions to visualize different aspects of vacuum impregnation of Minas cheese. LWT-Food Sci Technol 38: 379-386

Mariscal M, Bouchon P (2008) Comparison between atmospheric and vacuum frying of apple slices. Food Chem 107: 1561-1569

Sahin S, Sumnu SG (2009) Introduction In: Advances in Deep-Fat Frying of Foods. Sahin S, Sumnu S G (Ed.). CRC Press, New York. pp 1-32

Sharanabasava, Ravindra MR, Praveen KYS, Manjunatha M, Kumar MG, Nath BS (2019) Evaluation of vacuum impregnation as a novel 
approach for soaking of fried Gulabjamun balls. J Food Sci Technol https://doi.org/10.1007/s13197-019-03734-5.

Sharanabasava, Ravindra MR, Praveen KY S, Shivanand, Arjun VM, Adarsh MK (2018) Changes in moisture and fat content of Gulabjamun balls during sub-baric frying and vacuum impregnation. Intl J Chem Stud 6: $1108-1111$

Varela G (1988). Current facts about the frying of food. In: Frying of food: Principles, changes, new approaches. Varela, G, Bender A E and Morton I D (Ed.). Ellis Horwood, Chichester. pp 9-25
Wasnik PG, Menon RR, Nath BS, Balasubramanyam BV, Manjunatha M, Sivaram M (2017) Application of particle analysis and colour parameters for detection of adulteration of cow ghee with vanaspati derived from image analysis. Indian J Dairy Sci 70: 200-208

Yam KL, Papadakis SE (2004) A simple digital imaging method for measuring and analyzing color of food surfaces. J Food Engg 61:137142

Yamsaengsung, R, Ariyapuchai, T, Prasertsit, K (2011). Effects of vacuum frying on structural changes of bananas. J Food Engg 106: 298-305 